\title{
AZ EGÉSZSÉGMŰVELTSÉG ÉS A TÁPLÁLKOZÁSI SZOKÁSOK KÖZÖTTI ÖSSZEFÜGGÉS VIZSGÁLATA SERDÜLŐK KÖRÉBEN
}

\author{
Szerzők: \\ Tuza Alexandra \\ Debreceni Egyetem \\ Szőllősi Gergő József \\ Debreceni Egyetem \\ Szőnyi Krisztina \\ Debreceni Egyetem \\ Barth Anita \\ Debreceni Egyetem \\ Első szerző e-mail címe: \\ szandituza98@gmail.com
}

Lektorok:

Dr. Nagy Attila Csaba

Debreceni Egyetem

Dr. Legoza József

Debreceni Egyetem

...és további két anonim lektor

\begin{abstract}
Absztrakt
A fiatalkorban kialakuló nem megfelelő táplálkozási szokások felnőttkorban számos betegség kialakulásához vezethetnek. Célunk a serdülők egészségműveltségi szintjének feltérképezése és az ezt befolyásoló tényezők vizsgálata. Az egészségműveltség szintjének meghatározására a The Newest Vital Sign (NVS) tesztet használtuk. Szignifikáns összefüggést találtunk az egészségműveltségi szint és a rostos üdítőital fogyasztás között $(p=0,037)$. Magas a problémás egészségműveltséggel rendelkezők aránya, mely a rostos üdítőital fogyasztásával mutatott összefüggést.
\end{abstract}

Kulcsszavak: egészségműveltség, NVS, serdülők, táplálkozási szokások

Diszciplina: egészségtudomány

\begin{abstract}
MEASURING THE RELATIONSHIP BETWEEN

HEALTH LITERACY AND EATING HABITS AMONG ADOLESCENTS

Inadequate eating habits at a young age can lead many diseases in adulthood. The aim of the study was to measure the health literacy level of adolescents and to examine the
\end{abstract}


factors that may influence it. The health literacy level was measured with the Newest Vital Sign (NVS) test. We found a significant correlation between the level of health literacy and the consumption of soft drinks $(p=0,037)$. Inadequate health literacy was high among students, which was related to the consumption of soft drinks.

Keywords: health literacy, NVS, adolescents, eating habits

Disciplines: health science

Tuza Alexandra, Szőllősi Gergő József, Szőnyi Krisztina és Barth Anita (2020): Az egészségműveltség és a táplálkozási szokások közötti összefüggés vizsgálata serdülők körében. OxIPO - interdiszciplináris tudományos folyóirat, 2020/3, 19-29. doi: 10.35405/OXIPO.2020.3.19

A serdülők egészségmagatartásának és egészségműveltségi szintjének feltérképezése elengedhetetlen a hatékony egészségnevelési és egészségfejlesztési stratégiák kialakításához és azok módszertani fejlesztéséhez. Mind a lakosság (Papp és mtsai, 2016), mind pedig a serdülők (Nagy és mtsai, 2015) egészségműveltség vizsgálatára volt példa hazánkban, ugyanakkor legjobb tudásunk szerint az egészségmúveltség és az egészségmagatartás összefüggését vizsgáló kutatás még nem történt. A nemzetközi irodalomban fellelhető tanulmányok azonban rávilágítottak arra, hogy az egészségműveltség és az egészség- és rizikómagatartás között öszszefüggés áll fenn (Fleary, Joseph, és Pappagianopoulos, 2017).

Vizsgálatunkkal célunk a serdülők egészségműveltségének és egészségmagatartásának (különös tekintettel a táplálkozási szokásokra) feltérképezése, annak érdekében, hogy a vizsgált intézményekben célzott, személyre szabott intervenciók kerülhessenek kidolgozásra. A következőkben a serdülők körében végzett egészségműveltség vizsgálatokra, valamint az egészségmagatartást célzó felmérésekre fókuszálunk. Ismertetésre kerülnek továbbá keresztmetszeti kutatásunk legfrissebb eredményei is.

\section{AZ EGÉSZSÉGMƯVELTSÉG JELENTŐSÉGE A SERDÜLŐK KÖRÉBEN}

Az egészségműveltség és annak vizsgálata napjainkban egyre többet kutatott terület. Multidimenzionális fogalomként emlegetik. Egy tanulmány 17 különböző definícióját említi az egészségműveltségnek (Csizmadia, 2016; Nagy és mtsai, 2015). Leggyakrabban azonban a WHO fogalmát idézik, mely szerint az egészségműveltség „az emberek kognitív és szociális készsége (skills), amely meghatározza az egyének motivációját és az egyé- 
nek képességét (ability), amely segítségével hozzáférnek, megértik és felhasználják azokat az információkat, amelyek elősegítik és fenntartják jó egészségüket” (Csizmadia, 2016).

Az egészségműveltség mérésére számos mérőeszközt fejlesztettek ki. A nemzetközi irodalomban azonban több olyan teszt is található, amelyet az egészségműveltség mérésére használtak a serdülők körében. Egy napjainkban megjelent összefoglaló tanulmány összesen 29 db mérőeszközt mutat be részletesen azok előnyeivel, hátrányaival együtt (Guo és mtsai, 2018). A kérdőívek közül elsősorban az általunk is alkalmazott Newest Vital Sign (NVS) teszttel mért fontosabb nemzetközi eredményeket szeretnénk bemutatni.

Az NVS tesztet 2004-ben Weiss és munkatársai (Weiss és mtsai, 2005) fejlesztették ki a felnőttek egészségműveltségének vizsgálatára. A teszt szövegértési képességet, számolási készséget és problémamegoldó képességet egyaránt mér. A válaszadóknak összesen hat kérdésre kell válaszolniuk egy jégkrémes doboz táplálkozási adatait tartalmazó címke alapján. Összesen 6 pont szerezhető, a pontozás pedig az alábbiak szerint alakul:

0-1 pont: nagy valószínűséggel korláto zott,

2-3 pont: valószínúleg korlátozott,

4-6 pont: nagy valószínűséggel megfelelő egészségműveltségi szint.

Néhány évvel ezelőtt a teszt gyermekek és serdülők körében végzett sikeres validálását mutatták be (Driessnack és mtsai, 2014; Warsh és mtsai, 2013). Driessnack és munkatársai 7 éves kor fölötti gyermekek körében már ajánlják a teszt használatát, ezzel szemben Warsh és munkatársai úgy gondolják, hogy a teszt 10 éves kor fölött használható csak megbízhatóan. Driessnack és munkatársai által végzett felmérés érdekessége, hogy a tesztet nem csupán a gyermekek, de a szülők körében is felvették. A résztvevők $72 \%$-a nagy valószínűséggel megfelelő egészségműveltségi szinttel rendelkezik, tehát többségük a 6 pontból 4 vagy több pontszámot ért el. Nem mutattak ki szignifikáns különbséget a szülők (átlagpontszám $4,8 \pm 1,6$ ) és a gyermekeik (átlagpontszám

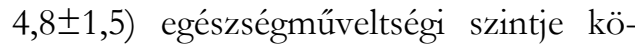
zött. Ugyanakkor közöttük pozitív korreláció volt tapasztalható. Mindemellett összefüggést találtak a háztartásban előforduló gyermekkönyvek száma és az egészségműveltségi szint között. Azokban a családokban, ahol 10-nél kevesebb gyermekkönyv fordult elő a gyermek és a szülő egyaránt alacsonyabb egészségmúveltségi szinttel rendelkezett, tehát valamennyi esetben 4 pontnál kevesebbet értek el (Driessnack és mtsai, 2014). Ezen eredmények hatására több országban alkalmazták sikeresen a tesztet a fiatalok körében.

Az Amerikai Egyesült Államokban a 6. osztályosok körében (átlagéletkor: 11,1士 0,24 év) végzett felmérés eredményei alapján elmondható, hogy a tanulók 62,9\%-a nagy valószínűséggel megfelelő, míg 12,6\%-a nagy valószínűséggel korlá- 
tozott egészségműveltségi szinttel rendelkezik. A maximális 6 pontból a vizsgálatban résztvevők 3,75 pontot értek el (szórás: 1,70). A nemek között szignifikáns különbség nem volt kimutatható (nő át-

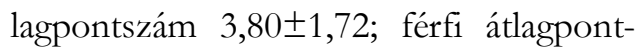

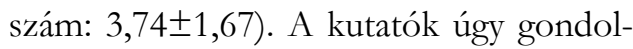
ják, hogy az NVS teszt önállóan is megállja a helyét úgy a klinikai gyakorlatban, mint az iskolai felhasználás során (Linnebur és Linnebur, 2016).

A nemzetközi irodalomban fellelhetô néhány, a serdülők körében végzett, kifejezetten az egészség- és rizikómagatartás, valamint az egészségműveltség összefüggését vizsgáló tanulmány is. Egy 2017-ben megjelenő áttekintő tanulmány azon kutatásokat gyűjtötte össze és elemezte, melyek középpontjában a serdülőkori egészségmagatartás, valamint az egészségmüveltség vizsgálata állt. Az eredmények pedig arra engednek következtetni, hogy a kettő szoros kapcsolatban áll egymással (Fleary, Joseph, és Pappagianopoulos, 2017).

\section{A SERDÜLŐK EGÉSZSÉGMAGATARTÁSÁT CÉLZÓ VIZSGÁLATOK}

A HBSC (Health Behaviour In Schoolaged Children) kutatás az Egészségügyi Világszervezettel együttműködésben zajló nemzetközi keresztmetszeti kutatás, amely az 5., 7., 9. és 11. osztályos diákok egészségmagatartását vizsgálja.
Hazánk először 1986-ban csatlakozott a négy évenkénti gyakorisággal ismétlődő kutatáshoz, melynek napjainkban már több mint 40 ország a tagja (Németh és Költő, 2011; Németh és Költő, 2016). A 2014-es felmérés során használt kérdőív az alábbi témaköröket érintette: egészségmagatartás (táplálkozási szokások, fizikai aktivitás, rizikómagatartások stb.), szubjektív jóllét (önértékelt egészség, krónikus betegségek és állapotok, élettel való elégedettség stb.) és háttértényezők (demográfia, család, kortársak stb.).

Összességében elmondható, hogy az évek során, hol pozitív, hol negatív változások következtek be a fiatalok táplálkozási szokásaiban, de ezek nem kielégítőek az egészségük szempontjából.

A hazai adatok azonban elszomorítóak. Közismert tény ugyanis, hogy a megfelelő mennyiségú és minőségű táplálékbevitel gyermekkorban a legjelentősebb, hiszen biztosítja az optimális növekedést és hozzájárul a szellemi fejlődéshez (Schaub és Bácsi, 2011). Helyes táplálkozással a betegségek egyharmada megelőzhető lenne. Ennek ellenére világszerte az egyik legfőbb probléma a zsírban és koleszterinben gazdag táplálkozás, amely különféle negatív hatásokhoz vezet. Az állandó és nagymértékü cukrozott üdítőitalok bevitelének szintén negatív irányú hatása van, hiszen sok fruktózt tartalmaznak, ami növeli a szérum húgysavat és a köszvény kockázatát (Choi és mtsai, 2007). A gyermekek körében egyre gyakoribb az elhízás, a 2-es típusú diabetes mellitus, vala- 
mint szív- és érrendszeri betegségek (Besenyei és mtsai, 2014; Cselik, 2017; Boros és mtsai, 2018).

\section{MÓDSZER}

\section{Minta}

A végleges mintanagyságot befolyásolta az adatfelvétel napján hiányzó tanulók, illetve a kérdőív kitöltését visszautasító

A vizsgálatban két intézmény 5., 7. és 9. évfolyamos tanulók ( $\mathrm{n}=206$ fö) vettek részt, akiknek átlagéletkora 13,89 év (szórás: 1,80) volt. A nemek megoszlásánál elmondható, hogy a résztvevők 53,88\%-a lány, 46,12\%-a fiú.

A legnagyobb arányban a 9. évfolyamról vettek részt a tanulók (5. évfolyam: 23,30\%; 7 évfolyam: 16,99\%; 9. évfolyam: 60,19\%). Az évfolyamok közötti nem egyenlő arányú megoszlás hátterében két tényező áll. Egyrészt az 5. és a 7. évfolyamon a kérdőív kitöltésének idején igen magas volt a hiányzók aránya, másrészt a 9. évfolyamon a teljes létszámot tekintve is jóval többen vannak, mint a vizsgált másik két évfolyamon.

A szülők iskolai végzettsége az alábbiak szerint alakult: az édesanyák 15,13\%-a alapfokú, 38,35\%-a középfokú és 46,12\%a pedig felsőfokú iskolai végzettséggel rendelkezik, az édesapák 14,56\%-a alapfokú, 40,29\%-a középfokú, 45,15\%-a felsőfokú iskolai végzettséggel rendelkezik (1. táblázat).
1. táblázat: $A$ résztvevoók $(n=206)$ szociodemográfiai adatai (forrás: a Szerzoók)

\begin{tabular}{lll}
\hline Változók & & Résztvevők \\
\hline Átlagéletkor & & $\begin{array}{l}13,89 \text { év } \\
\text { (szórás=1,80 év) }\end{array}$ \\
\hline Nem & Nő & $53,88 \%(\mathrm{~N}=111)$ \\
& Férfi & $46,12 \%(\mathrm{~N}=95)$ \\
\hline Évfolyam & 5. osztály & $23,30 \%(\mathrm{~N}=48)$ \\
& 7. osztály & $16,99 \%(\mathrm{~N}=35)$ \\
& 9. osztály & $60,19 \%(\mathrm{~N}=124)$ \\
\hline Édesanya & Alapfokú & $15,13 \%(\mathrm{~N}=32)$ \\
iskolai & Középfokú & $38,35 \%(\mathrm{~N}=79)$ \\
végzettsége & Felsőfokú & $46,12 \%(\mathrm{~N}=95)$ \\
\hline Édesapa & Alapfokú & $14,56 \%(\mathrm{~N}=30)$ \\
iskolai & Középfokú & $40,29 \%(\mathrm{~N}=83)$ \\
végzettsége & Felsőfokú & $45,15 \%(\mathrm{~N}=93)$ \\
\hline
\end{tabular}

\section{Eszközök}

A papír alapú kérdőív kitöltése a tanulók számára önkéntes és anonim volt. A kérdőív összesen 3 nagy témakört érintett. A kérdőív első része a szocio-demográfíai adatokra vonatkozó kérdéseket tartalmazta és az alábbi területekre kérdezett rá: nem, életkor, osztály, lakóhely, szülők iskolai végzettsége.

A második részben az egészségmagatartásra vonatkozó kérdések találhatók. A kérdések alapjául a HBSC kutatások során alkalmazott kérdőív kérdései szolgáltak. Beválogatásra kerültek a táplálkozás minőségére vonatkozó alábbi kérdések:

- „Hány alkalommal fogyasztasz gyümölcsöt?”

- „Hány alkalommal fogyasztasz zöldséget?"

- „Hány alkalommal fogyasztasz teljes kiőrlésű kenyeret/graham/?” 
- „Hány alkalommal fogyasztasz gyorséttermi ételeket?”

- „Hány alkalommal fogyasztasz édességet (csokoládé, cukor, sütemény)?”

- „Hány alkalommal fogyasztasz rágcsálnivalót (chips, mogyoró)?”

- „Hány alkalommal fogyasztasz rostos üdítőitalt (Sió, Rauch)?”

- „Hány alkalommal fogyasztasz szénsavas üdítőitalt (kóla, Fanta)?”

- „Hány alkalommal fogyasztasz szénsavasmentes vizet?”

- „Hány alkalommal fogyasztasz energiaitalt?"

- „Hány alkalommal fogyasztasz kávét?"

A kérdőív harmadik részben található az egészségműveltséget mérő teszt, mely a szövegértési képességet, a számolási készséget és a problémamegoldó képességet is méri. A válaszadóknak hat kérdést kell megválaszolniuk egy jégkrémes doboz táplálkozási adatait tartalmazó címke segítségével. Az első négy kérdés méri elsősorban az alapvető számolási készséget:

- „Ha megeszi az egész doboz jégkrémet, mennyi kalóriát fogyaszt el?"

- „Ha 60 g szénhidrátot fogyaszthat édesség gyanánt, mennyit ehet meg a dobozból?"

- „Orvosa azt tanácsolta, hogy csökkentse a telített zsírok fogyasztását. Általában 42 g telített zsírt fogyaszt, beleértve 1 adag jégkrémet is. Ha nem enne többé jégkrémet, hány gramm telített zsírt fogyasztana naponta?”
- „Ha naponta átlagosan 2500 kalóriát fogyaszt, akkor egy adag jégkrém elfogyasztása ennek mekkora hányadát (hány százalékát) teszi ki?”

Az utolsó két kérdés pedig a kitöltő szövegértési képességéről ad tájékoztatást:

• „Tegyük föl, hogy Ön allergiás a következőkre: penicillin, mogyoró, latex kesztyű, méhcsípés. Ennek tudatában biztonságos-e, ha eszik ebből a jégkrémből?"

- „Miért?”

Ugyanakkor minden kérdés az egyén problémamegoldó képességéről is információt ad. A Newest Vital Sign teszt alapján (ahol összesen 6 pont volt szerezhetô) három kategóriába lehet besorolni a tanulókat egészségmûveltségi szintjük alapján, ezek pedig a következők: nagy valószínűséggel megfelelő (4-6 pont), valószínűleg korlátozott (2-3 pont) és nagy valószínűséggel korlátozott (0-1pont).

\section{Eljárás}

Csoportos mintavételi eljárás keretében került sor az adatfelvételre 2019 márciusmájus hónapjaiban. A kérdőívek kitöltése az iskolai osztálytermekben történt, osztályfőnöki óra keretén belül, előre egyeztetett időpontban. Az adatfelvétel hossza osztályonként változott: az 5. osztályos tanulóknál körülbelül egy iskolai tanórát, azaz 45 percet, még a 7 . osztályosnál 30 percet, a 9. osztályos diákoknál pedig 1520 percet vett igénybe. A felmérés kitöltése során személyesen is jelen voltunk, így a felmerülő kérdésekre választ adhattunk. 
Az adatok feldolgozása és elemzése a Stata Statistical Software: Release 13. statisztikai szoftvercsomag alkalmazásával történt. A kérdésekre adott válaszok a megjelölt válaszok függvényében részarányokkal (\%) kerülnek bemutatásra. A kategorikus változók gyakoriságbeli eltéréseit Khí-négyzet próbák segítségével értékeltük. Az eredmények közötti eltérést abban az esetben tekintettük szignifikánsnak, ha az adott statisztikai eljárásból származó p-érték kisebb volt, mint 0,05.

\section{Eredmények}

A serdülōk táplálkozási szokásai

A táplálkozás minőségére vonatkozó eredmények könnyebb értelmezhetősége miatt az egyes változók esetében két kategóriát hoztunk létre: ajánlásoknak megfelelő, ajánlásoknak nem megfelelő táplálkozás. A kategóriák létrehozásánál figyelembe vettük a magyar táplálkozási ajánlásokat. Mindezek alapján elmondható (v.ö.: 2. táblázat), hogy az ajánlásoknak megfelelően, tehát naponta egyszer vagy annál

2. táblázat: A vizsgálatban rész̧vevö tanulók táplálkozási szokásai $(N=206)$. Forrás: a Szerzőo

\begin{tabular}{|c|c|c|c|c|c|}
\hline \multirow[b]{2}{*}{ TERMÉK } & \multicolumn{5}{|c|}{ A FOGYASZTÁS GYAKORISÁGA } \\
\hline & $\begin{array}{l}\text { Naponta } \\
\text { többször }\end{array}$ & $\begin{array}{c}\text { Naponta } \\
\text { egyszer }\end{array}$ & $\begin{array}{l}\text { Hetente } \\
\text { legalább } \\
\text { egyszer }\end{array}$ & $\begin{array}{l}\text { Ritkábban, } \\
\text { mint hetente }\end{array}$ & Soha \\
\hline Rostos üdítőital & $\begin{array}{c}6,76 \% \\
(\mathrm{~N}=14)\end{array}$ & $\begin{array}{l}26,57 \% \\
(\mathrm{~N}=55)\end{array}$ & $\begin{array}{l}38,65 \% \\
(\mathrm{~N}=80)\end{array}$ & $\begin{array}{l}19,81 \% \\
(\mathrm{~N}=41)\end{array}$ & $\begin{array}{l}8,21 \% \\
(\mathrm{~N}=17)\end{array}$ \\
\hline Szénsavas üdítőital & $\begin{array}{l}7,73 \% \\
(\mathrm{~N}=16)\end{array}$ & $\begin{array}{l}24,15 \% \\
(\mathrm{~N}=50)\end{array}$ & $\begin{array}{l}42,51 \% \\
(\mathrm{~N}=88)\end{array}$ & $\begin{array}{l}18,36 \% \\
(\mathrm{~N}=38)\end{array}$ & $\begin{array}{l}7,25 \% \\
(\mathrm{~N}=15)\end{array}$ \\
\hline Szénsavmentes víz & $\begin{array}{l}55,34 \% \\
(\mathrm{~N}=114)\end{array}$ & $\begin{array}{l}22,33 \% \\
(\mathrm{~N}=46)\end{array}$ & $\begin{array}{l}9,71 \% \\
(\mathrm{~N}=20)\end{array}$ & $\begin{array}{l}4,37 \% \\
(\mathrm{~N}=9)\end{array}$ & $\begin{array}{l}8,25 \% \\
(\mathrm{~N}=17)\end{array}$ \\
\hline Energiaital & $\begin{array}{l}4,88 \% \\
(\mathrm{~N}=10)\end{array}$ & $\begin{array}{l}9,76 \% \\
(\mathrm{~N}=20)\end{array}$ & $\begin{array}{l}16,59 \% \\
(\mathrm{~N}=34)\end{array}$ & $\begin{array}{l}17,56 \% \\
(\mathrm{~N}=36)\end{array}$ & $\begin{array}{c}51,22 \% \\
(\mathrm{~N}=105)\end{array}$ \\
\hline Kávé & $\begin{array}{l}2,90 \% \\
(\mathrm{~N}=6)\end{array}$ & $\begin{array}{l}10,14 \% \\
(\mathrm{~N}=21)\end{array}$ & $\begin{array}{l}15,46 \% \\
(\mathrm{~N}=32)\end{array}$ & $\begin{array}{l}13,53 \% \\
(\mathrm{~N}=28)\end{array}$ & $\begin{array}{c}57,97 \% \\
(\mathrm{~N}=120)\end{array}$ \\
\hline Gyümölcs & $\begin{array}{l}21,84 \% \\
(\mathrm{~N}=45)\end{array}$ & $\begin{array}{l}40,78 \% \\
(\mathrm{~N}=87)\end{array}$ & $\begin{array}{l}29,13 \% \\
(\mathrm{~N}=60)\end{array}$ & $\begin{array}{l}6,80 \% \\
(\mathrm{~N}=14)\end{array}$ & $\begin{array}{l}1,46 \% \\
(\mathrm{~N}=3)\end{array}$ \\
\hline Zöldség & $\begin{array}{l}11,59 \% \\
(\mathrm{~N}=24)\end{array}$ & $\begin{array}{l}45,41 \% \\
(\mathrm{~N}=94)\end{array}$ & $\begin{array}{l}35,75 \% \\
(\mathrm{~N}=74)\end{array}$ & $\begin{array}{l}5,80 \% \\
(\mathrm{~N}=12)\end{array}$ & $\begin{array}{l}1,45 \% \\
(\mathrm{~N}=3)\end{array}$ \\
\hline $\begin{array}{l}\text { Teljes kiörlésű } \\
\text { kenyér }\end{array}$ & $\begin{array}{l}18,36 \% \\
(\mathrm{~N}=38)\end{array}$ & $\begin{array}{l}29,47 \% \\
(\mathrm{~N}=61)\end{array}$ & $\begin{array}{l}20,29 \% \\
(\mathrm{~N}=42)\end{array}$ & $\begin{array}{l}14,49 \% \\
(\mathrm{~N}=30)\end{array}$ & $\begin{array}{l}17,39 \% \\
(\mathrm{~N}=36)\end{array}$ \\
\hline Gyorséttermi étel & $\begin{array}{l}1,94 \% \\
(\mathrm{~N}=4)\end{array}$ & $\begin{array}{l}4,37 \% \\
(\mathrm{~N}=9)\end{array}$ & $\begin{array}{l}31,55 \% \\
(\mathrm{~N}=65)\end{array}$ & $\begin{array}{l}54,85 \% \\
(\mathrm{~N}=113)\end{array}$ & $\begin{array}{l}7,28 \% \\
(\mathrm{~N}=15)\end{array}$ \\
\hline Édesség & $\begin{array}{l}13,59 \% \\
(\mathrm{~N}=28)\end{array}$ & $\begin{array}{l}44,17 \% \\
(\mathrm{~N}=91)\end{array}$ & $\begin{array}{l}33,50 \% \\
(\mathrm{~N}=69)\end{array}$ & $\begin{array}{c}6,80 \% \\
(\mathrm{~N}=14)\end{array}$ & $\begin{array}{l}1,94 \% \\
(\mathrm{~N}=4)\end{array}$ \\
\hline Sós rágcsálnivaló & $\begin{array}{l}9,18 \% \\
(\mathrm{~N}=19)\end{array}$ & $\begin{array}{l}24,15 \% \\
(\mathrm{~N}=50)\end{array}$ & $\begin{array}{l}52,66 \% \\
(\mathrm{~N}=109)\end{array}$ & $\begin{array}{l}11,59 \% \\
(\mathrm{~N}=24)\end{array}$ & $\begin{array}{l}2,42 \% \\
(\mathrm{~N}=5)\end{array}$ \\
\hline
\end{tabular}


többször a tanulók 57,00\%-a zöldséget, 62,62\%-a gyümölcsöt és $77,67 \%$-a szénsavmentes vizet fogyaszt. Teljes kiölésû kenyeret naponta, vagy legalább hetente egyszer 68,12\%-a eszik a serdülőknek.

A gyorséttermi ételek esetében elmondható, hogy a tanulók 62,13\%-a ritkábban, mint hetente vagy egyáltalán nem fogyaszt ilyen ételeket. Az ajánlásoknak megfelelően, tehát hetente egyszer, vagy ennél is ritkábban a tanulók 42,24\%-a édességet, míg 66,67\%-a sós rágcsálnivalók eszik. Ritkábban, mint hetente a tanulók 19,81\%-a rostos üdítőt, 25,61\%-a pedig szénsavas üdítőt fogyaszt. Soha nem iszik energiaitalt a tanulók 51,22\%-a, kávét a tanulók pedig 57,97\%-a (2. táblázat).

\section{A serdülōk egészségmüveltségi szintje}

Az NVS teszt alapján a vizsgálatban részt vevő fiatalok 50,49\%-a nagy valószínűséggel megfelelő, 23,30\%-a valószínúleg korlátozott, míg 26,21\%-a nagy valószínűséggel korlátozott kategóriába került (1. ábra).

Az egészségmúveltségre vonatkozó eredmények könnyebb értelmezhetősége miatt két kategóriát hoztunk létre: az NVS teszten 4 vagy annál magasabb pontszám elérése esetén az egyén a megfelelő, míg ez alatti pontszám esetén a nem megfelelő egészségműveltségi kategóriába került. Ez alapján az alábbiak szerint alakul a százalékos megoszlás: A tanulók 50,49\%-a megfelelő egészségműveltségi kategóriába kerül, míg 49,51\%-a nem megfelelő egészségműveltségi kategóriába esik.
1. ábra: A serdülōk egészségmüveltségi szintje (N=206). Forrás: a Szerzőo

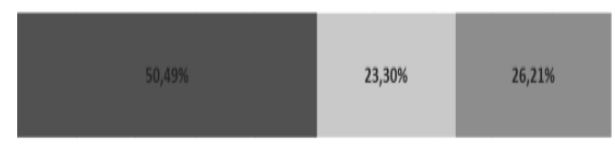

- nagy valószinüséggel megfelelö "| valószinüleg korlátozott In nagy valószinüséggel korlátozott

Nem találtunk szignifikáns összefüggést a két intézmény tanulói között az egészségműveltség vonatkozásában $(\mathrm{p}=0,376)$. A következőkben ezért a két intézmény tanulóit egy egységként kezeljük, az összefüggéseket pedig a teljes mintára vonatkozóan $(\mathrm{N}=206)$ mutatjuk be.

Összességében elmondható, hogy nem találtunk szignifikáns összefüggést az egészségműveltség és a zöldség-, gyümölcs-, teljes kiőrlésű kenyér, gyorséttermi ételek, édesség, valamint sós rágcsálnivaló fogyasztása között. A szénsavas üdítőital, szénsavmentes víz, energiaital, valamint a kávé fogyasztása sem bizonyult befolyásoló tényezőnek.

Ugyanakkor szignifikáns összefüggést találtunk az egészségműveltség és a rostos üdítőital fogyasztás közötti $(p=0,037)$. Azok a serdülők, akik megfelelő egészségműveltségi kategóriába esnek, nagyobb valószínűséggel fogyasztanak az ajánlásoknak megfelelően rostos üdítőitalt a nem megfelelő egészségműveltségi kategóriába eső serdülőkhöz képest (2. ábra). 
2. ábra: Az egészségmüveltség és a rostos üdítôital fogyasztás közötti összefüggés ( $N=206)$. Forrás: a Szerző́k

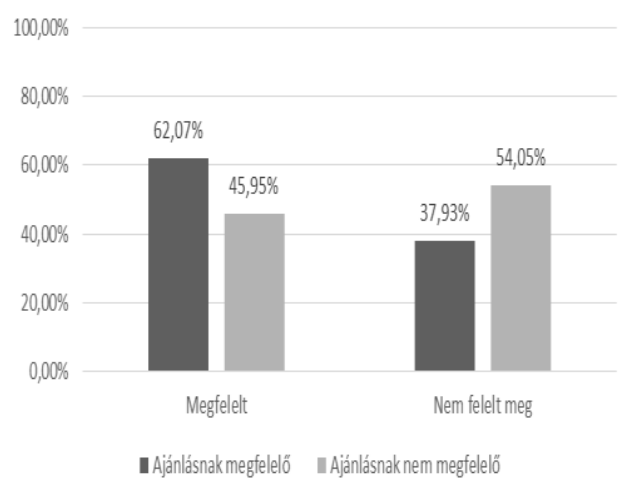

\section{MEGVITATÁS}

Összességében elmondható, hogy a tanulók esetében a teljes kiőrlésű pékáruk, valamint a szénsavmentes víz fogyasztása közelít leginkább az ajánlásokhoz. Javítandó azonban a gyümölcs-, a zöldségfogyasztás. Csökkentésre szorul a kávé-, az energiaital-, az édesség-, a sós rágcsálnivalók-, a gyorséttermi ételek-, valamint a rostos- és szénsavas üdítőitalok fogyasztásának gyakorisága.

Ugyan a résztvevők fele nagy valószínúséggel megfelelő egészségműveltséggel rendelkezik, nem szabad figyelmen kívül hagyni azt a tényt, hogy a nemzetközi eredményekkel összevetve a vizsgálatunkban részt vevő tanulók rosszabb eredményeket értek el az egészségmúveltség vonatkozásában (Linnebur és Linnebur, 2016). Az egészségműveltség és a táplálkozás minősége közötti összefüggéseket vizsgálva a rostos üdítőital tekintetében találtunk szignifikáns összefüggést ( $p=0,037)$. Úgy tűnik tehát, hogy azok a tanulók, akik magasabb egészségmúveltségi kategóriába tartoznak a rostos üdítőitallal kapcsolatos ajánlásokkal jobban tisztában vannak, ezért kerülik annak fogyasztását.

\section{KORLÁTOZÁSOK}

Esetünkben egy anonim kérdőíves felmérésről van szó, mely felmérésnek végleges mintanagyságát a mintavétel napján hiányzott tanulók létszáma, illetve a kitöltést megtagadó tanulók létszáma befolyásolta. A kapott eredményekből nem vonhatóak le általános következmények, csupán az adott intézmények tanulóira vonatkoztathatóak az eredmények. Mivel a választott egészségműveltséget mérő kérdőívvel nem állnak rendelkezésre hazai, iskoláskorúak körében végezett vizsgálatok, így nincs lehetőség eredményeink összevetésére hazai vizsgálatok eredményeivel.

\section{KONKLÚZIÓK}

A vizsgált intézményekben vannak fejlesztésre szoruló területek - mind az egészséges táplálkozás, mind pedig az egészségműveltség vonatkozásában. Ennek javítása érdekében kiemelt jelentőségû az egészségtudatosság javítása, az egészségmagatartás fejlesztése a különféle egészségnevelési és egészségfejlesztési 
programok fejlesztését célzó intézkedések révén. Fontos nem csupán a tanulók, de a szülők körében történő felvilágosítás, tájékoztatás is, annak érdekében, hogy valódi, mérhető változás következzen be.

A jövőben nagyobb, reprezentatív mintán érdemes a vizsgálatot megismételni.

\section{IRODALOM}

Besenyi G., Barczi Sz., Pongor V. és Forrai J. (2014). Általános iskolás tanulók táplálkozási- és egészségmagatartási szokásai. Egészségtudomány, (58)2. 3648.

Boros J., Györke J., Stokker E. és Szabó Zs. (2018). A 2014-ben végrehajtott Európai lakossági egészségfelmérés eredményei Összefoglaló adatok. ELEF Mühelytanulmány I. Központi Statisztikai Hivatal, Budapest.

Choi, J. W. J., Ford, E. S., Gao, X., és Choi, H. K. (2007). Sugar-sweetened soft drinks, diet soft drinks, and serum uric acid level: The third national health and nutrition examination survey. Arthritis \& Rheumatism, 59(1), 109-116. DOI: $\underline{10.1002 / \text { art.23245 }}$

Cselik B. (2017). Egészségfejlesz̨tő program hatása általános iskolás diákok egészségmagatartására (,Fitness”, vagy ,fatness”?! Avagy nem lehet elég korán kezdeni). Doktori (Ph.D.) értekezés. Pécsi Tudományegyetem Egészségtudományi Kar, Doktori Iskola, Pécs.
Csizmadia P. (2016). Az egészségmúveltség definíciói. Egészségfejlesz̨tés, (57)3. 41-44.

Driessnack, M., Chung, S., Perkhounkova, E. és Hein, M. (2014). Using the "Newest Vital Sign" to Assess Health Literacy in Children. Journal of Pediatric Health Care, 28(2), 165-171. DOI: 10.1016/j.pedhc. 2013.05.005

Fleary, S. A., Joseph, P. és Pappagianopoulos, J. E. (2017). Adolescent health literacy and health behaviors: A systematic review. Journal of Adolescence, 62, 116-127. DOI: 10.1016/j.adolescence.2017.11.010

Guo, S., Armstrong, R., Waters, E., Sathish, T., Alif, S. M., Browne, G. R. és Yu, X. (2018). Quality of health literacy instruments used in children and adolescents: a systematic review. BMJ Open, 8(6), e020080. DOI: 10.1136/bmjopen-2017-020080

Linnebur, L. A., Linnebur, S. A. (2016). Self-Administered Assessment of Health Literacy in Adolescents Using the Newest Vital Sign. Health Promotion Practice, 19(1), 119-124. DOI: $\underline{10.1177 / 1524839916677729}$

Nagy L., Korom E., Hódi Á. és Németh M. (2015). Az egészségműveltség online mérése. In: Csapó B. és Zsolnai A. (szerk.): Online diagnosztikus mérések az iskola kezdô" szakaszában. Oktatáskutató és Fejlesztő Intézet, Budapest. 147177. 
Németh Á. és Költő A. (2011). Serdülókorú fiatalok egészsége és életmódja. Az Iskoláskorú gyermekek egészségmagatartása címü, az Egészségügyi Világszervezettel együttmüködésben zajló nemzetközi kutatás 2010. évi felméréséröl keészült nemzeti jelentés. Országos Gyermekegészségügyi Intézet, Budapest.

Németh Á. és Költő A. (2016). Egészség és egészségmagatartás iskoláskorban. Az Iskoláskorú gyermekek egészségmagatartása elnevezésü, az. Egészségügyi Világszervezettel együttmüködésben megvalósuló nemzetközi kutatás 2014. évi felméréséröl készült nemzeti jelentés. Nemzeti Egészségfejlesztési Intézet, Budapest.

Papp O., Náfrádi L., Schulz P. és Csabai M. (2016). „Hogy minden beteg megértse!" - Az egészségműveltség (health literacy) mérése Magyarországon. Orvosi Hetilap, 157(23). 905-915.
Schaub G. és Bácsi K. (2011). Táplálkozási szokások nemzetközi összehasonlítása 10-12 éves gyermekek körében. Iskolakultura, 2011/10-11. 138-146.

Warsh, J., Chari, R., Badaczewski, A., Hossain, J. és Sharif, I. (2013). Can the Newest Vital Sign Be Used to Assess Health Literacy in Children and Adolescents? Clinical Pediatrics, 53(2), 141-144. DOI: $10.1177 / 0009922813$ $\underline{504025}$

Weiss, B. D., Mays, M. Z., Martz, W., Castro, K. M., DeWalt, D. M., Pignone, M. P., Mockbee, J., és Hale, F. A. (2005). Quick Assessment of Literacy in Primary Care: The Newest Vital Sign. The Annals of Family Medicine, 3(6), 514-522. DOI: $\underline{10.1370 / \mathrm{afm} .405}$ 